\title{
The Impacts of COVID-19 Pandemic on Demographics and Management of Acute Coronary Syndromes: A Referral PCI Center Perspective
}

\author{
COVID-19 Pandemisinin Akut Koroner Sendromların Demografik Özellikleri ve Yönetimi Üzerine Etkisi: \\ Sevk Merkezi Olan Bir PKG Kliniğinin Perspektifi \\ Ali Çoner ${ }^{1}$, Emre Ertürk ${ }^{2}$, Salih Kılıç ${ }^{3}$, Uğur Önsel Türk ${ }^{2}$ \\ ${ }^{1}$ Baskent University Hospital Alanya Application and Research Center, Department of Cardiology, Alanya, Turkey \\ ${ }^{2}$ Izmir Economy University Faculty of Medicine, Department of Cardiology, Izmir, Turkey \\ ${ }^{3}$ Health Sciences University Adana Training and Research Hospital, Department of Cardiology, Adana, Turkey
}

\begin{abstract}
Introduction: In the COVID-19 era, concerns about risks of transmission withdraw patients to admit to hospitals and to take medical help for even emergency situations such as acute coronary syndromes (ACS). The study aims to obtain impacts of the COVID-19 pandemic on ACS demographics and to compare the same time period in 2019 from a referral percutaneous coronary intervention $(\mathrm{PCl})$ center perspective.

Methods: The study was conducted using anonymous data from a referral $\mathrm{PCl}$ center that provides care for more than 2 million habitants throughout Northern Izmir. Hospital admissions and emergency medical services transfers with a diagnosis of ACS were documented for the time period between $11^{\text {th }}$ March and $11^{\text {th }}$ June 2020 and for the same time period in 2019 retrospectively. Data about demographics, clinical presentation, and management strategies were collected and compared between the same time periods in 2019 and 2020.

Results: Overall ACS admissions were found to be decreased $6.0 \%$ from 2019 (480 patients) to 2020 (451 patients); however, decrement in the first 3 weeks following the World Health Organization (WHO) declaration on pandemic was sharper (26.7\%). Patients over 65 years of age, gender, and type of ACS presentation were not different between 2019 and 2020. Higher rates of $\mathrm{PCl}(51.3 \%$ vs. $59.2 \%)$ and lower rates of Coronary Artery Bypass Grafting (13.5\% vs. $10.9 \%$ ) as a destination therapy for revascularization were observed in 2020 than 2019 ( $p=0.049$ ).

Conclusion: A slight decrease was detected in emergency admissions for ACS in the study. Interventional cardiologists may develop a tendency to perform the final decision for revascularization in the catheter laboratory.
\end{abstract}

Key words: COVID-19 pandemic, Acute coronary syndromes, Interventional cardiac procedures

\section{INTRODUCTION}

SARS-CoV-2 related COVID-19 pandemic affected countries all over the world and global outbreak still continues. Pandemic era changed daily life and public

\section{ÖZET}

Giriş: COVID-19 döneminde hastaların bulaş riskinden tedirgin olmaları nedeniyle hastane başvuruları ve tıbbi tedavi alma talepleri akut koroner sendromlar (AKS) gibi acil olan durumlar dahil azalmıştır. Bu çalışmada sevk merkezi olan bir Perkütan koroner girişim (PKG) kliniğinde COVID-19 pandemisinin AKS hastalarının demografik özellikleri üzerine etkisini araştırmayı ve 2019 yılının aynı aylarındaki verilerle karşılaştırmayı amaçladık.

Yöntemler: Çalışma, İzmir'in kuzeyinde 2 milyondan fazla nüfusa bakım sağlayan bir sevk PKG merkezinden alınan anonim veriler kullanılarak gerçekleştirildi. AKS tanısı ile hastaneye kabuller ve acil sağlık hizmetleri transferleri 11 Mart-11 Haziran 2020 tarihleri arasında ve aynı dönem için 2019'da geriye dönük olarak belgelendi. Demografik özellikler, klinik prezentasyon ve hasta yönetim stratejileri ile ilgili veriler toplandı ve 2019 ve 2020'deki aynı zaman aralıkları arasında karşılaştırıldı.

Bulgular: Genel AKS başvurularının 2019'dan (480 hasta) 2020'ye (451 hasta) \%6,0 azaldığı bulundu; ancak Dünya Sağlık Örgütü'nün (WHO) pandemiye ilişkin açıklamasını takip eden ilk 3 haftada düşüş daha keskin olarak tespit edildi (\%26,7). 65 yaşın üzerindeki hastalar, cinsiyet ve AKS prezentasyonu 2019 ve 2020 arasında farklı değildi. 2020'de 2019'a kıyasla revaskülarizasyon için hedef tedavi olarak PKG oranları daha yüksek (\%51,3 vs. $\% 59,2$ ) ve Koroner arter bypass cerrahisi oranları daha düşük $(\% 13,5$ vs. $\% 10,9)$ saptandı $(p=0,049)$.

Sonuç: Çalışmada AKS hastalarının başvurularında hafif bir azalma tespit edildi. Girişimsel kardiyologların, revaskülarizasyon için hedef tedaviyi kateter laboratuarında gerçekleştirme eğilimlerinde artış gözlendi.

Anahtar Kelimeler: COVID-19 pandemisi, Akut koroner sendromlar, Girişimsel kardiyak işlemler

healthcare costs were also increased. Extremely increased numbers of need for mechanical ventilation devices and intensive care unit hospitalizations overwhelmed healthcare systems. On the other hand, 
concerns about risks of transmission withdraw patients to admit to hospitals and to take medical help for even emergency situations such as acute coronary syndromes (ACS). Turkey is one of the last countries announced first proven COVID-19 case, at March 11th, 2020 (1). Following the announcement of first case in Turkey, national government ordered a partial lockdown especially involving citizens over 65 years of age who were thought under to have an increased risk situation. Within the course of outbreak, a general curfew order for weekends was also approved in Turkey.

With the onset of COVID-19 era, many healthcare workers reported a decline in hospital admissions related to ACS. Even studies were published about the effect of COVID-19 outbreak on the decrement in ACS hospitalizations (2-5). Decreased ACS admissions increased concerns among cardiologists about an increase in cardiac mortality and as well as an increase in morbidities such as heart failure syndromes in long term. Some clinicians claimed that either partial lockdown policies depending on population age or concerns of citizens about staying in hospital environment might play role in the decreased number of ACS hospitalizations. Turkish Society of Cardiology published an expert opinion paper about the management of cardiac patients including especially ACS presentations during the ongoing COVID-19 era (6).

In this study, we aimed to observe the effect of COVID19 pandemic for 3 months period from March 11th to June 11th 2020 on the number of ACS hospitalizations in a high volume, referral catheter center which is capable of performing 7/24 percutaneous coronary interventions $(\mathrm{PCl})$ and compare the acquired data with the same time period of 3 months of 2019.

\section{METHODS}

\section{Study Population:}

This single center, retrospective cohort study enrolled the patients with ACS who had admitted to the referral center and other health care providers in same geographic region. The study was conducted using anonymous data from a referral $\mathrm{PCl}$ center with 2 cardiac catheterization laboratories and inpatient clinics that provides care for more than 2 million habitants throughout Northern Izmir. Individual cases were searched from the referral center database, starting at March $11^{\text {th }} 2020$, the day which the first proven case was detected in Turkey (1) to June $11^{\text {th }}$ 2020. March $11^{\text {th }} 2020$ is also the day which World Health Organization (WHO) declared COVID-19 as a global pandemic around the World (7). Hospital admissions and interventional procedures for ACS patients between March $11^{\text {th }}$ and June $11^{\text {th }} 2020$ were compared with the same time period of March $11^{\text {th }}$ and June $11^{\text {th }}$ of the year 2019. Demographic characteristics of patients such as age, gender, type of ACS presentation and the final decision for the management of ACS were recorded for both 2019 and 2020. The dataset was also evaluated for 3 month period from March to June for 2020 and changes in demographics of ACS patients and trends for the management were searched while the COVID-19 pandemic was going on. The ethical approval was obtained from the local ethical committee.

\section{Statistical Analysis:}

For discrete and continuous variables, descriptive statistics (mean, SD, median, IQR, and percentile) were calculated. The assumption of normality was tested via the Kolmogorov-Smirnov test. To compare the differences between the 2 groups, the Student-t test was used when the parametric test prerequisites were fulfilled, and the Mann-Whitney $U$ test was used when such prerequisites were not met. The data were evaluated using IBM SPSS Statistics for Windows, Version 22.0 (IBM Corp., Armonk, NY, USA). P values $<0.05$ was accepted as statistically significant. 


\section{RESULTS}

Overall number of admissions or referrals with ACS decreased from 480 in 2019 to 451 in 2020 (6.0\% overall decrement). We observed a higher decrement in ACS admissions/referrals as $26.7 \%$ for the time period between March 11th and April 2nd, 2020 compared to same time period in 2019 (ACS admissions decreased from 127 to 93 in first 3 weeks within pandemic declaration of $\mathrm{WHO}$ ).

At demographics perspective, mean age had a tendency to be lower but this did not reach a statistical significance $(62.2 \pm 12.8$ vs. $60.7 \pm 12.8$ years $)(p=0.083)$. Patients' ratio older than 65 years of age $(43.5 \%$ vs. $40.5 \%)$ and female gender ratio (30.8\% vs. $31.5 \%)$ were similar between the years ( $p$ values were 0.360 and 0.830 , respectively) (Table 1 ).

Relative percentage of patients treated via $\mathrm{PCl}$ was higher in 2020 (51.3\% vs. 59.2\%) ( $p=0.049)$. Coronary artery bypass grafting (CABG) ratio (13.5\% vs. $10.9 \%)$ and patients who managed medically $(35.5 \%$ vs. 29.9\%) were lower in 2020 than 2019 (Table 1). Overall mortality rate was similar between the years $(2.3 \%$ vs. $0.9 \%)(p=0.089)$. Number of stents implanted per patient were not different between the years (1.45 vs. 1.36) $(\mathrm{p}=0.190)$.

\section{DISCUSSION}

Although we detected a $6.0 \%$ decrement in admissions/referrals for ACS in first 3 months of COVID-19 pandemic than respective period of the previous year, this slight decrease was much lower than previous studies conducted mainly in European countries (2-4). Also in another study from Turkey, a $58.3 \%$ decrease was reported in acute MI hospitalizations in COVID-19 era (5). On the other side, these studies report the ACS admission decrements for only the first few weeks of global outbreak. Similarly, we also detected a higher decrease (26.7\%) in ACS admissions/referrals within the first 3 weeks (between $11^{\text {th }}$ March and $2^{\text {nd }}$ April, 2020) following the announcement of first COVID-19 case in Turkey (1). This decrease was much similar to previous studies however it is still lower than them. We think that referral position of the study center rather than admission center only may have a role on slight decrement in ACS volume in pandemic era. It is also possible that the decrements in numbers of admissions due to patient's contamination fear and drawbacks about health care provider is major driver in decrements in overall ACS volume in pandemic era. However, at referral center perspective these reasons were not valid and not have substantial effect in ACS volume of the center. Study center is a high volume, tertiary, referral catheterization center for interventional cardiology procedures, so this also might play a role in slighter decrease in ACS volume compared to previous reports.

In our analysis, mean age had a tendency to be lower than the same 3 months period in 2019 but this was not statistically significant $(p=0.083)$. With the announcement of first case in Turkey, a curfew order for citizens who are older than 65 years of age and also who are with chronic illnesses was approved by the national government and this factor might play pivotal role for younger ACS hospitalizations in the course of pandemic (8). Following these curfew orders, concerns about the medical management of ACS patients over 65 years of age have arised among cardiologists (6). Unfortunately, we do not have any data about the probable cardiac death rates in older patients during the course of COVID-19 outbreak yet. These concerns also exist about the possible future increase in patients with intractable heart failure symptoms. We think that statistical analysis of patients with de novo heart failure admissions should be monitored closely in the forthcoming days in Turkey.

We also observed an increased tendency to perform $\mathrm{PCl}$ rather than $\mathrm{CABG}$ referral in pandemic era. An increase in rate of patients who were treated with $\mathrm{PCl}$ 
Table 1. Demographic characteristics and trends in clinical management between 2019 and 2020 for ACS patients.

\begin{tabular}{|c|c|c|c|}
\hline & $\begin{array}{l}2019 \text { (480 patients) } \\
\text { (March } 11^{\text {th }} \text {-June } 11^{\text {th }} \text { ) }\end{array}$ & $\begin{array}{c}2020 \text { (451 patients) } \\
\left(\text { March } 11^{\text {th }} \text {-June } 11^{\text {th }}\right)\end{array}$ & p value \\
\hline Age (meanıSD) & $62.2 \pm 12.8$ & $60.7 \pm 12.8$ & 0.083 \\
\hline $\begin{array}{l}\text { Percentage of patients over } 65 \text { years of age } \\
(\%, N)\end{array}$ & 43.5 (209) & $40.5(183)$ & 0.360 \\
\hline Female gender $(\%, N)$ & $30.8(148)$ & $31.5(142)$ & 0.830 \\
\hline $\begin{array}{l}\text { Clinical presentation }(\%, \mathrm{~N}) \\
\begin{array}{l}\text { - } \\
\text { - NSAP } \\
\text { - STEMMI } \\
\text { STEMI }\end{array}\end{array}$ & $\begin{array}{l}26.9(129) \\
50.8(244) \\
22.3(107)\end{array}$ & $\begin{array}{l}23.1(104) \\
49.7(224) \\
27.3(123)\end{array}$ & 0.153 \\
\hline $\begin{array}{l}\text { Preferred treatment }(\%, \mathrm{~N}) \\
\begin{array}{l}\text { - } \\
\text { PCI } \\
\text { - } \text { CABG } \\
\text { - Medical }\end{array}\end{array}$ & $\begin{array}{c}51.3(246) \\
13.5(65) \\
35.2(169)\end{array}$ & $\begin{array}{c}59.2(267) \\
10.9(49) \\
29.9(135)\end{array}$ & 0.049 \\
\hline $\begin{array}{l}\text { Average number of stents used for } \mathrm{PCl} \\
\text { patients (mean } \pm \mathrm{SD} \text { ) }\end{array}$ & $1.45(0.76)$ & $1.36(0.74)$ & 0.190 \\
\hline
\end{tabular}

was observed from $51.3 \%$ to $59.2 \%$ in 2020 compared to 2019 with the onset of outbreak. At the same time a decrease in CABG rates was also observed from $13.5 \%$ to $10.9 \%$ as a destination therapy in ACS patients $(\mathrm{p}=0.049)$. Although statistically borderline decrements in the rates of $C A B G$ or the increase of $\mathrm{PCl}$ numbers have small differences from the previous year, we think that heart team of the study center have a tendency to withdraw from longer hospitalizations or more aggressive revascularization techniques such as CABG in COVID era. Studies documenting the trends in coronary revascularization options in COVID era are limited. In a preliminary report, CABG population size in March and April 2020 was observed as 61\% of CABG population in 2019. This sharp decrease in CABG rates became lesser when statistical data was expended to a there is no data about the comparison of $\mathrm{PCl}$ vs. $\mathrm{CABG}$ rates as revascularization choice in ACS population. In our study, we observed a trend to $\mathrm{PCl}$ as a destination therapy in ACS population and withdrawal from more complex revascularization procedures and longer hospitalizations.

\section{CONCLUSION}

In conclusion, this preliminary report showed us that partial restraints cover older citizens might have a role in the decreasing mean age of ACS admissions. Interventional cardiologists developed a tendency to finish ACS patients' revascularization in the catheter laboratory and $\mathrm{PCl}$ rates as a destination therapy for revascularization increased compared to previous year. Nationwide close monitoring about de novo heart failure rates should be discussed strongly in the future. 
Conflict of Interest: The authors declare that they have no conflict of interest.

Funding: No funding was taken for this study.

Acknowledgements: Authors thanked to Nesrin Solbaz for her invaluable contribution.

\section{REFERENCES}

1. Ministry of Health of Turkey. Current status in Turkey. 2020. Available from: https://covid19.saglik.gov.tr . Accessed September 20, 2020).

2. De Rosa S, Spaccarotella C, Basso C, et al. Società Italiana di Cardiologia and the CCU Academy investigators group. Reduction of hospitalizations for myocardial infarction in Italy in the COVID-19 era. Eur Heart J. 2020;41(22):2083-8.

3. Metzler B, Siostrzonek P, Binder RK, et al. Decline of acute coronary syndrome admissions in Austria since the outbreak of COVID-19: the pandemic response causes cardiac collateral damage. Eur Heart J. 2020;41(19):1852-3.
4. Moroni F, Gramegna M, Ajello S, et al. Collateral damage: Medical care avoidance behavior among patients with myocardial infarction during the COVID-19 pandemic. JACC Case Rep. 2020;2(10):1620-4.

5. Kundi $H$, Balcı MM, Güngörer $B$, et al. Trends in acute myocardial infarction admissions during the COVID-19 pandemic in Ankara, Turkey. Anatol J Cardiol. 2020;24(2):81-2.

6. Aktoz M, Altay $\mathrm{H}$, Aslanger $\mathrm{E}$, et al. [Turkish Cardiology Association Consensus Report: COVID-19 Pandemic and Cardiovascular Diseases (May 13, 2020)]. Turk Kardiyol Dern Ars. 2020;48(Suppl 1):1-87.

7. World Health Organization. Available from: https://who.int/dg/speeches/detail/who-director-general-sopening-remarks-at-the-media-briefing-on-covid-19---11-march2020. Accessed:September 20, 2020.

8. Coronavirus: Turkey restrains older citizens from leaving homes. Available from: https://www.aa.com.tr/en/turkey/coronavirusturkey-restrains-older-citizens-from-leaving-homes/1774287. Accessed:September 20, 2020.

9. Casey L, Khan N, Healy DG. The impact of the COVID-19 pandemic on cardiac surgery and transplant services in Ireland's National Centre. Ir J Med Sci. 2021;190(1):13-7.

Cite as: Çoner A, Ertürk E, Kılıç S, Türk UÖ. The Impacts of COVID-19 Pandemic on Demographics and Management of Acute Coronary Syndromes: A Referral PCI Center Perspective. Eskisehir Med J. 2021;2(3):148-152. 